J. Perinat. Med.

1 (1973) 205

\title{
The influence of acidity on hematocrit and hemoglobin values in newborn infants immediately after delivery
}

\author{
G. Bacigalupo, E. Z. Saling \\ Unit for Perinatal Medicine \\ The Free University of Berlin, Germany \\ Received March 30, 1973. Accepted April 20, 1973
}

In a previous work concerning the dependence of the hemoconcentration on blood $\mathrm{pH}$ we described significant increases of hematocrit and hemoglobin values in acidotic newborn infants immediately post partum [1]. The $\mathrm{pH}$ values then measured represented, of course, a measure of the momentary hydrogen ion concentrations in the samples investigated; they gave, however, no information about the proportion of organic acids (formed predominantly by glycolysis) in the total acidity.

The present study has two major objectives in view. On the one hand, it should clarify whether and to what extent a conformity of the effects of total acidity and metabolic acidity on the hemoconcentration in the neonate exists. On the other hand, it should answer the question as to whether the oxygen partial pressure in the cord blood of the neonate correlates in any way with the hemoconcentration, since increases in blood acidity leading to hemoconcentration are very frequently the consequence of hypoxic episodes during labor.

\section{Subjects and methods}

In the course of our study 314 term babies were examined immediately after delivery. They had all been born per vaginam. Neonates suffering from morbus haemolyticus fetalis were not included in the investigation.

In all cases determinations of the $\mathbf{p H}$, of the hematocrit and of the hemoglobin in umbilical artery blood were made. The hydrogen ion concentration was measured in a SALING-TURowskI-pH-meter. For hematocrit determinations the micro-method of STRUMTA, SAMPLE and HART [7] was used. Hemoglobin was colorimetrically determined applying the hemiglobin cyanide method of VAN KAMPEN and ZijLSTRA [3].

\section{Curriculum vitae}

Giovanni Bacigalupo, Priv.-Doz. Dr. med. babil. 1925: Born in Berlin, Germany, on February 23 rd. 1950: $M$. D. (Internal Medicine), Humboldt University, Berlin. 1950-1956: Clinical education in internal medicine at Berlin. 1956-1957: Postdoctoral research fellow (endocrinology'), University of Rome. 1957-1962: Clinical research assistant and later

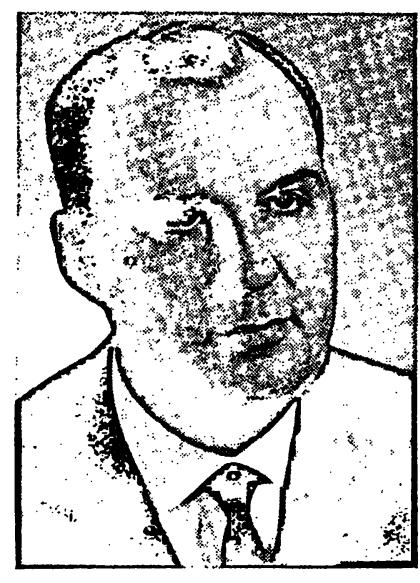
senior assistant, Tumor Clinic, Berlin-Buch, German Academy of Sciences. 1962-1969: Head of the Department of Internal Medicine and Cancer Chemotherapj, Clinical Division of the Institute of Cancer Research, Berlin-Buch, German Academy of Sciences. Since 1970 Head of Section "Metabolism and Endocrinolog)", Unit for Perinatal Medicine, The Free University of Berlin.

Main research interests: Patbophysiology of the buman fetus in the perinatal period. Hormone metabolism during pregnancy.

In 277 of the neonates examined the metabolic acidity in umbilical artery blood was estimated. The degree of metabolic acidity was assayed by $\mathrm{pH}$ measurement at a standardized $\mathrm{CO}_{2}$ pressure of $40 \mathrm{mmHg}$ [6]. In order to produce this carbon dioxide pressure, the blood sample was put into a small equilibration chamber thermostated at $37^{\circ} \mathrm{C}$, and a humidified mixture of 5.6 per cent carbon dioxide and 94.4 per cent oxygen $(v / v)$ was bubbled through it for 3 minutes. Equilibration and subsequent $\mathrm{pH}$ measurement were made in the abovementioned type of $\mathrm{pH}$-meter. The $\mathrm{pH}$ value being measured in the sample after in-vitronormalization of the $\mathrm{PCO}_{2}$ - the so-called $\mathrm{pHqu} 40$ depends largely on the amount of organic acids (chiefly lactic acid) present in the fetal blood.

In 281 cases the oxygen partial pressure in umbilical artery blood was determined. The measurements were 
made by potentiometry in an Astrup apparatus, produced by RADIOMETER Inc., Copenhagen.

The blood samples were obtained from umbilical arteries by puncture and blood aspiration, avoiding any contact with the air. The interval of time between blood withdrawal and beginning of laboratory processing of the samples did not usually exceed 5 minutes.

The clinical condition of the newborn infant immediately after delivery was described by means of our modified score system [5]. In this system 4 clinical signs are assessed: state of the umbilical ressels, skin color, muscle tone and movements, and respiration during the first 90 seconds after delivery. Each sign is given one of four scores, varying from 0 (the worst) to 3 (the best). Thus, the total score may range from 0 to 12 points.

Based on the individual $\mathrm{pH}$ and $\mathrm{pHqu} 40$ values in umbilical artery blood, the cases in this study were divided into 5 groups (see Tabs. I and II). Cases showing $\mathrm{pH}$ or pHqu40 values between 7.25 and 7.39 were considered normal or almost normal as to their acidity; those with values from 7.20 to 7.24 were classified pre-acidotic; and those with values ranging from 7.00 to 7.19 were regarded as acidotic. As already suggested, the $\mathrm{pHqu} 40$ values chiefly reflect the strength of metabolic acidity which is essentially determined by the blood concentrations of organic acids formed in the glycolytic pathway. By contrast, the "simple" $\mathrm{pH}$ values - measured without previous in-vitro-normalization of the $\mathrm{CO}_{2}$ pressure in the blood sample - comprise the total acidity in the blood with both of its chief components, the metabolic and the respiratory.

\section{Results and comments}

As can be seen from Tabs. I and II, low $\mathrm{pH}$ and pHqu40 values are usually linked to decreased oxygen partial pressures. While in infants born with normal acid base status the mean $\mathrm{O}_{2}$ partial pressures in umbilical artery blood do not exceed $22 \mathrm{mmHg}$, the corresponding oxygen values of neonates suffering from preacidosis or acidosis lie below this level.

The insufficiently oxygenated fetus is forced to reduce its oxidative metabolism. Obeying the PASTEUR reaction, its energy requirement will now be met to a larger extent by anaerobic carbohydrate catabolism, i. e. by a compensatorily accelerated formation of lactic acid which represents the main source of metabolic acidity in the newborn infant immediately after delivery.

As a rule, rise of total and metabolic acidity leads to an advancing impairment of the neonate's clinical condition (see Tabs. I and II). The infants showing normal total and meta-
Tab. I Umbilical blood oxygen pressure and clinical state of the newborn immediately after delivery in different ranges of total acidity.

\begin{tabular}{rrrr}
\hline $\mathrm{pH}_{\mathrm{UA}}$ & No. & $\mathrm{Po}_{2} \mathrm{UA}(\mathrm{mmHg})$ & $\mathrm{Sa} \mathrm{S}$ \\
\hline $7.35-7.39$ & 33 & 26.9 & 9.7 \\
& & \pm 6.2 & \pm 1.6 \\
$7.30-7.34$ & 48 & 24.0 & 9.3 \\
& & \pm 6.2 & \pm 2.5 \\
$7.25-7.29$ & 93 & 22.2 & 9.4 \\
& & \pm 6.9 & \pm 1.2 \\
$7.20-7.24$ & 53 & 21.6 & 7.8 \\
$7.00-7.19$ & 54 & 17.0 & \pm 3.2 \\
& & \pm 5.1 & 7.5 \\
& & & \pm 2.3 \\
\hline
\end{tabular}

$\mathrm{pH}_{\mathrm{UA}}=$ hydrogen ions concentration in umbilical artery blood

No. = number of subjects examined

$\mathrm{Po}_{2} \mathrm{UA}=\mathrm{O}_{2}$ pressure in umbilical artery blood, arithmetical mean and standärd deviation

$\mathrm{Sa} S=$ SALING score, arithmetical mean in points and standard deviation

Tab. II Umbilical blood oxygen pressure and clinical state of the newborn immediately after delivery in different ranges of metabolic acidity.

\begin{tabular}{lrrr}
\hline pHqu40UA & No. & $\mathrm{Po}_{2} \mathrm{UA}_{\mathrm{A}}(\mathrm{mmHg})$ & $\mathrm{Sa} S$ \\
\hline $7.35-7.39$ & 25 & 25.6 & 9.7 \\
& & \pm 6.1 & \pm 1.9 \\
$7.30-7.34$ & 58 & 25.4 & 9.8 \\
& & \pm 7.0 & \pm 1.2 \\
$7.25-7.29$ & 79 & 22.3 & 9.4 \\
$7.20-7.24$ & 53 & \pm 5.9 & \pm 1.3 \\
& & 20.9 & 8.7 \\
$7.00-7.19$ & 35 & \pm 5.1 & \pm 2.3 \\
& & 16.0 & 6.7 \\
& & \pm 5.1 & \pm 2.4 \\
\hline
\end{tabular}

$\mathrm{pHqu}_{4 \mathrm{UA}}=$ metabolic acidity as judged by measurement of hydrogen ions concentration in umbilical artery blood, following in-vitro-normalization of carbon dioxide pressure.

Other denotations as in Tab. I.

bolic acidity $(\mathrm{pH}$ and $\mathrm{pHqu} 40$ above 7.25$)$ are on the average born in good condition (mean total scores above 9 points). In preacidosis and acidosis, however, the newborn infants are generally in poorer condition immediately after birth, as is indicated by the mean values of the individual total scores (mean total scores below 9). Again, these findings prove the causal inter- 
dependence of insufficient intrauterine oxygen supply, increase in acidity and impairment of the fetal and neonatal vitality.

Tab. III demonstrates the changes of the hematocrit and hemoglobin values in several physiological and pathophysiological ranges of total acidity. In newborn infants with normal $\mathrm{pH}$ values in umbilical artery blood the mean hematocrit values lie between 50 and 52 per cent; in contrast to this with pathologically lowered pH values $(<7.25)$ the hematocrit values rise up to 54.7 per cent. Similar to the changes of the hematocrit values, the hemoglobin values also show a tendency to rise with decreasing $\mathrm{pH}$. In infants showing a normal total acidity immediately after delivery the hemoglobin values range from 17.0 to 17.7 grams per 100 milliliters of blood, while in the preacidotic and acidotic infants the corresponding values rise to 18.0 and 18.4 grams per 100 milliliters of blood.

Tab. III Dependence of hematocrit and hemoglobin values upon total acidity.

\begin{tabular}{rrrr}
\hline & & & \multicolumn{1}{r}{$\mathrm{Hb}_{\mathrm{UA}}$} \\
$\mathrm{pH}$ & No. & Hct $\mathrm{UA}(\%)$ & $(\mathrm{g} . / 100 \mathrm{ml})$. \\
\hline $7.35-7.39$ & 47 & 50.0 & 17.0 \\
& & \pm 5.3 & \pm 2.2 \\
$7.30-7.34$ & 67 & 50.3 & 17.2 \\
& & \pm 5.3 & \pm 1.9 \\
$7.25-7.29$ & 93 & 52.0 & 17.7 \\
& & \pm 6.0 & \pm 1.9 \\
$7.20-7.24$ & 53 & 53.3 & 18.0 \\
& & \pm 5.9 & \pm 2.6 \\
$7.00-7.19$ & 54 & 54.7 & 18.4 \\
& & \pm 5.5 & \pm 2.2 \\
\hline
\end{tabular}

Hct $_{\text {A }}=$ hematocrit in umbilical artery blood

$\mathrm{Hb}_{\mathrm{A}}=$ hemoglobin content in umbilical artery blood

The influence of metabolic acidity on the hematocrit and hemoglobin values of neonates immediately post partum is demonstrated in Tab. IV. Again, we can observe the characteristic increase of hematocrit and hemoglobin values from 49.9 per cent and 17.0 grams per 100 milliliters of blood in the lowest range of metabolic acidity to 55.4 per cent and 18.8 grams per 100 milliliters of blood in the range of metabolic acidosis. Remarkably, the hematocrit and hemo- globin values are higher in the subjects suffering from metabolic preacidosis or acidosis ( $\mathrm{pHqu} 40$ 7.00 to 7.24 ) than in those suffering from preacidosis or acidosis as a result of increased total acidity ( $\mathrm{pH} 7.00$ to 7.24 ).

Tab. IV Dependence of hematocrit and hemoglobin values upon metabolic acidity.

\begin{tabular}{|c|c|c|c|}
\hline $\mathrm{pHqu} 40_{\mathrm{vA}}$ & No. & HetuA $_{\text {A }}(\%)$ & $\begin{array}{c}\text { Hbua } \\
\text { (g. } / 100 \mathrm{ml} .)\end{array}$ \\
\hline $7.35-7.39$ & 37 & $\begin{array}{r}49.9 \\
\pm 5.4\end{array}$ & $\begin{array}{r}17.1 \\
\pm 2.2\end{array}$ \\
\hline $7.30-7.34$ & 73 & $\begin{array}{r}50.3 \\
\pm 4.9\end{array}$ & $\begin{array}{r}16.9 \\
+1.8\end{array}$ \\
\hline $7.25-7.29$ & 79 & $\begin{array}{r}52.4 \\
\pm 5.6\end{array}$ & $\begin{array}{r}18.0 \\
\pm 2.2\end{array}$ \\
\hline $7.20-7.24$ & 53 & $\begin{array}{r}54.6 \\
\pm 6.5\end{array}$ & $\begin{array}{r}18.4 \\
\pm 2.2\end{array}$ \\
\hline $7.00-7.19$ & 35 & $\begin{array}{r}55.4 \\
\pm 4.7\end{array}$ & $\begin{array}{r}18.8 \\
\pm 2.0\end{array}$ \\
\hline
\end{tabular}

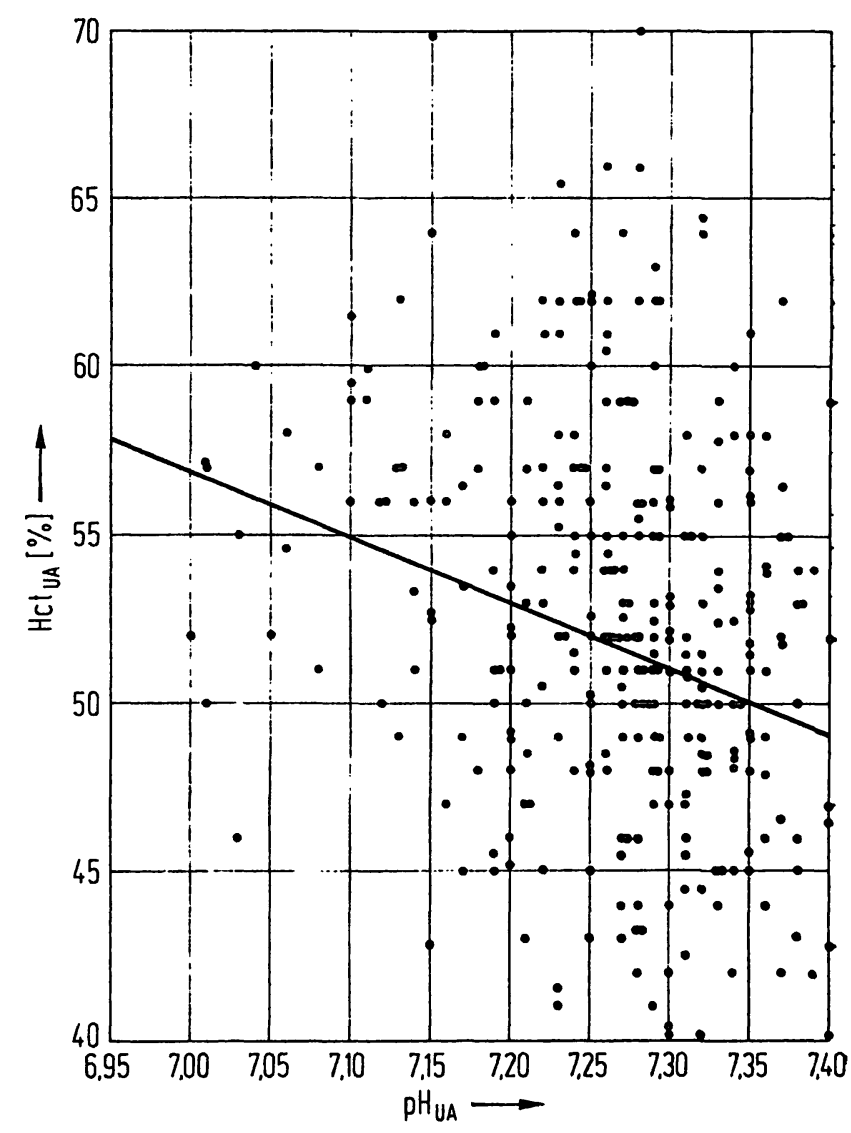

Fig. 1. Correlation between total acidity $\left(\mathrm{pH}_{U_{A}}=\mathrm{x}\right)$ and hematocrit $($ Hctus $=y$ ) in umbilical artery blood of 314 newborn infants immediately after delivery. Regression equation $\mathrm{y}=174.9-16.9 \mathrm{x} ; \mathrm{r}=0.24, v=312,2 \alpha<0.001$. 


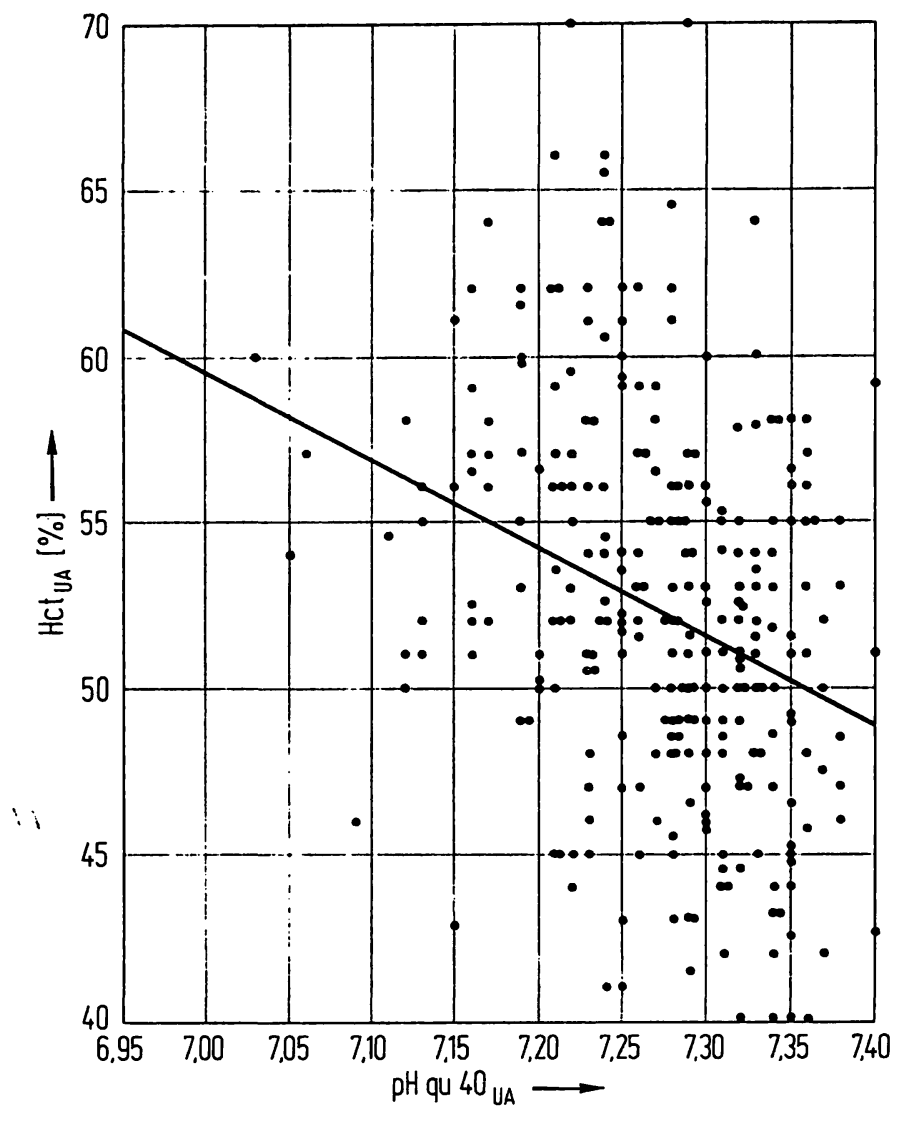

Fig. 2. Correlation between metabolic acidity (pHqu 40 va $=\mathrm{x})$ and hematocrit (HctuA $=y$ ) in umbilical artery blood of 277 newborn infants immediately after delivery. Regression equation $\mathrm{y}=244.7-26.5 \mathrm{x} ; \mathrm{r}=0.31, \nu=275$, $2 \alpha<0.001$.

Figs. 1 and 2 show the individual hematocrit values in relation to the individual $\mathrm{pH}$ and pHqu40 values. From the 314 paired values of $\mathrm{pH}$ and hematocrit and the 277 paired values of pHqu40 and hematocrit, the appropriate correlation coefficients and regression equations were computed (see legends of Figs. 1 and 2). In considering the large number of degrees of freedom, we find that the correlation between total acidity and hematocrit as well as that between metabolic acidity and hematocrit is statistically highly significant $(2 \alpha<0.001)$. Notably, the correlation between $\mathrm{pHqu} 40$ and hematocrit is considerably closer than that between $\mathrm{pH}$ and hematocrit.

The individual hemoglobin values in relation to the individual $\mathrm{pH}$ and $\mathrm{pHqu} 40$ values are demonstrated in Figs. 3 and 4. The correlation coefficients and regression equations for these paired observations are quoted in the legends of
Figs. 3 and 4. The correlation between $\mathrm{pH}$ and hemoglobin concentration in the neonate's umbilical artery blood is significant at the statistical level of $2 \alpha<0.01$; the correlation between pHqu40 and hemoglobin concentration is significant even at the level of $2 \alpha<0.001$.

From the regression equations of our random samples it can be derived that between the $\mathrm{pH}$ values of 7.40 and 7.00 a statistical rise of the hematocrit values from 49.2 to 56.9 per cent and of the hemoglobin concentrations from 17.1 to 19.1 grams per 100 milliliters of blood occurs. Accordingly, a decrease in blood pH of 0.1 units causes a statistical increase of 1.7 per cent in hematocrit and of 0.5 grams

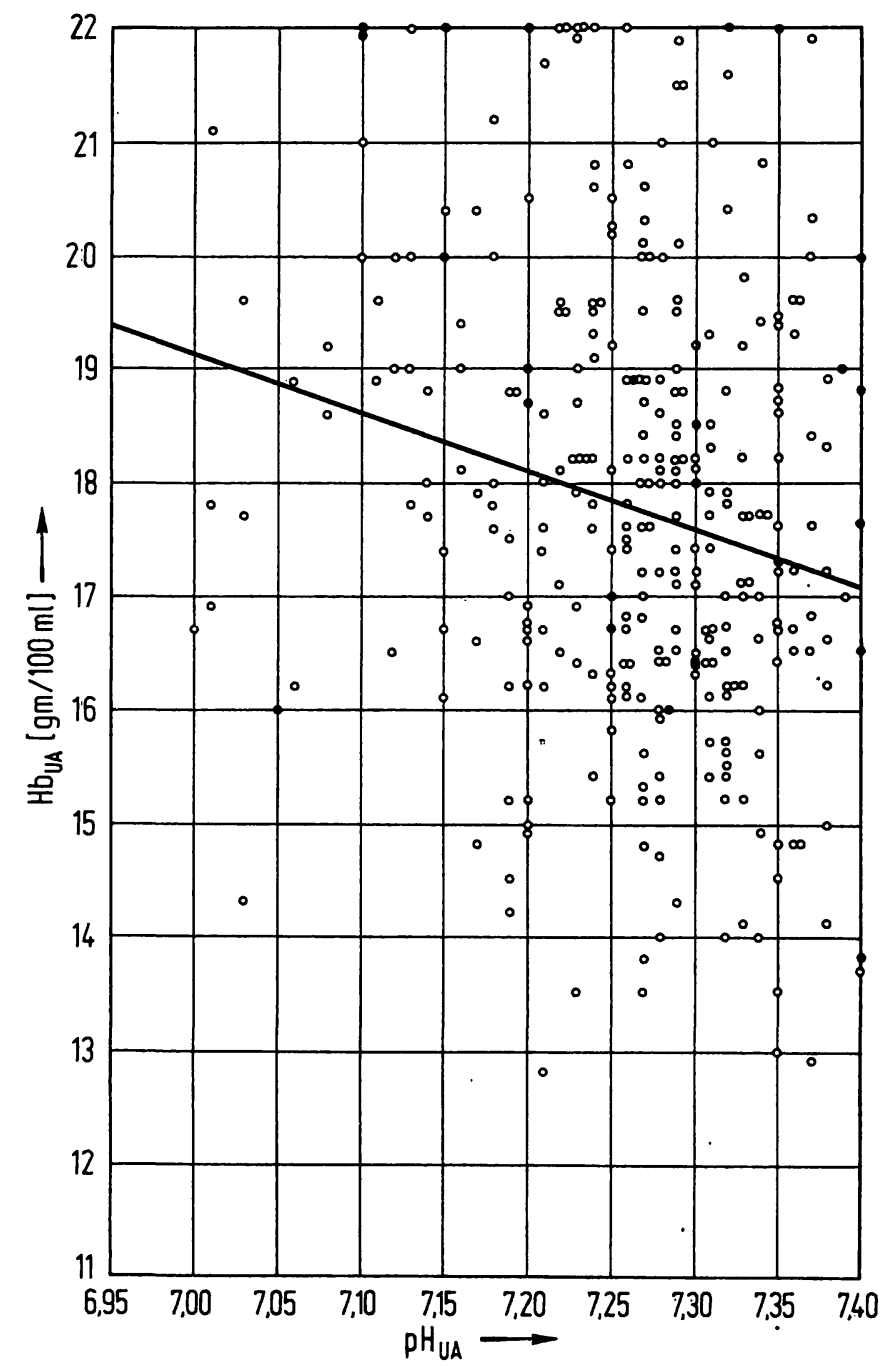

Fig. 3. Correlation between total acidity $\left(\mathrm{pH}_{U_{A}}=\mathbf{x}\right)$ and hemoglobin concentration ( $\mathrm{Hb}_{\mathrm{U}_{\mathrm{A}}}=\mathrm{y}$ ) in umbilical artery blood of 314 newborn infants immediately after delivery. Regression equation $\mathrm{y}=55.1-5.1 \mathrm{x} ; \mathrm{x}=0.19$, $\nu=312,2 \alpha<0.01$. 


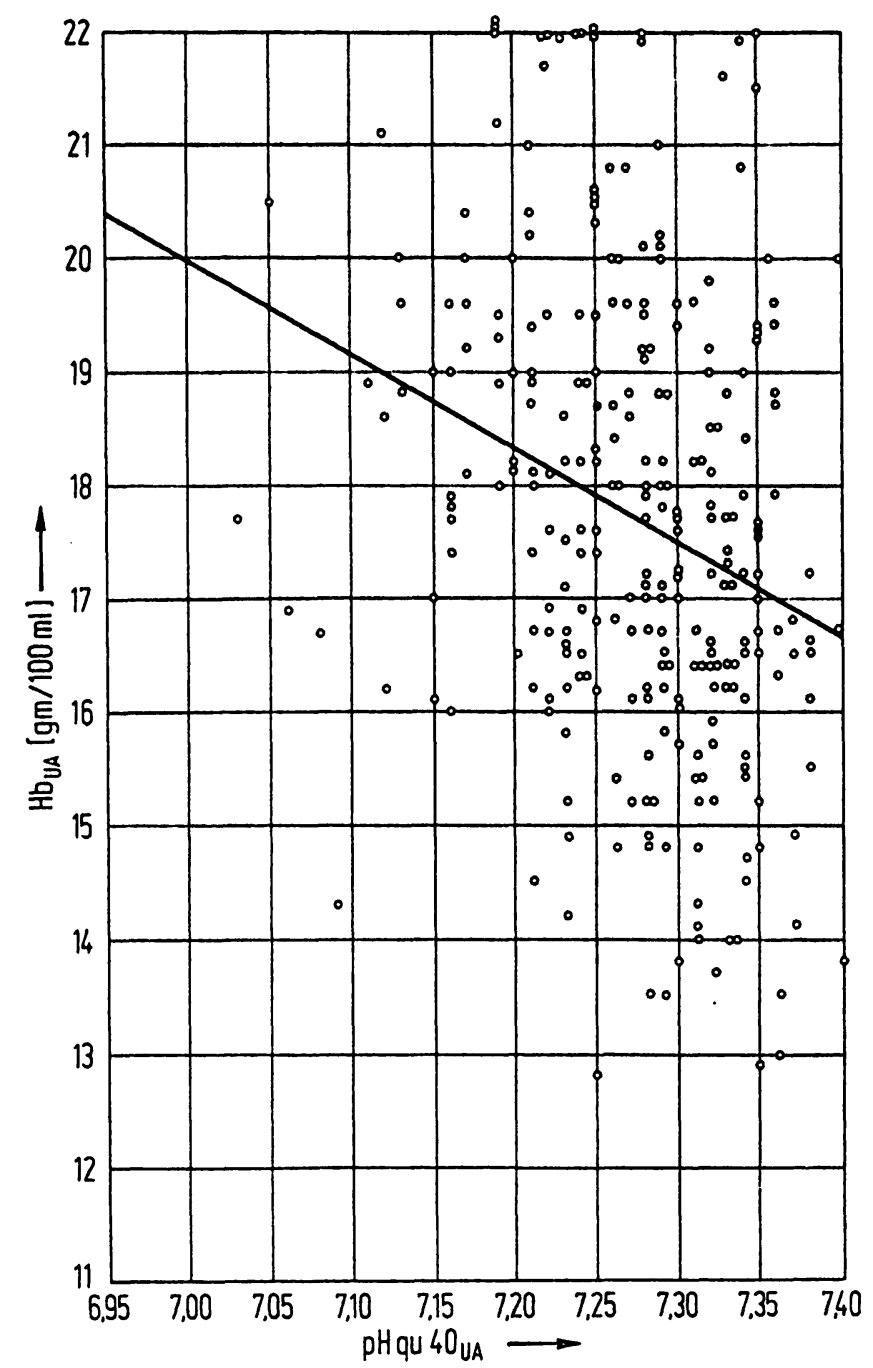

Fig. 4. Correlation between metabolic acidity (pHqu 40 UA $=x)$ and hemoglobin concentration ( $\left.\mathrm{HbuA}_{\mathrm{A}}=\mathrm{y}\right)$ inumbilical artery blood of 277 newborn infants immediately after delivery. Regression equation $\mathrm{y}=78.2-8.3 \mathrm{x}$; $r=0.26, v=275,2 \alpha<0.001$.

per 100 milliliters of blood in hemoglobin. Between pHqu40 7.40 and 7.00 an increase from 48.9 to 59.5 per cent in hematocrit and from 16.7 to 20.0 grams in hemoglobin per 100 nilliliters of blood is to be expected. Diminution of 0.1 units in pHqu40 is accompanied by a statistical rise of 2.6 per. cent in hematocrit and of 0.8 grams in hemoglobin per 100 milliliters of blood. It is likely that the nearly parallel increase in hematocrit and hemoglobin associated with the increase in neonatal blood acidity can be explained chiefly by hemoconcentration. This hemoconcentration seems to be a consequence of an increase in capillary permeability produced by oxygen deficiency with an enhanced passage of blood fluid into the interstitial space. Previous experiments with anesthesized pigs had already demonstrated that under conditions of controlled hypoxia a hemoconcentration can be provoked within a few minutes, the extent of which is dependent on the concomitant rise in acidity [2].

Theorctically it is also conceivable that, for instance, the considerable increases in hematocrit and hemoglobin found in newborn infants suffering from acidosis are evidence of an crythropocsis pathologically raised in response to a chronically reduced oxygen supply to the fetus. This hypothesis, however, does not appear to be very likely, since the acidotic neonates examined by us demonstrated no signs of retarded intrauterine growth, nor did their placentas show any striking weight differences compared to those of the non-acidotic neonates.

There are no significant correlations between oxygen partial pressures and hematocrit or hemaglobin concentrations in umbilical artery blood (Figs. 5 and 6), although fetal oxygen deficiency, increase in acidity and hemoconcentration are closely connected. Fetal oxy-

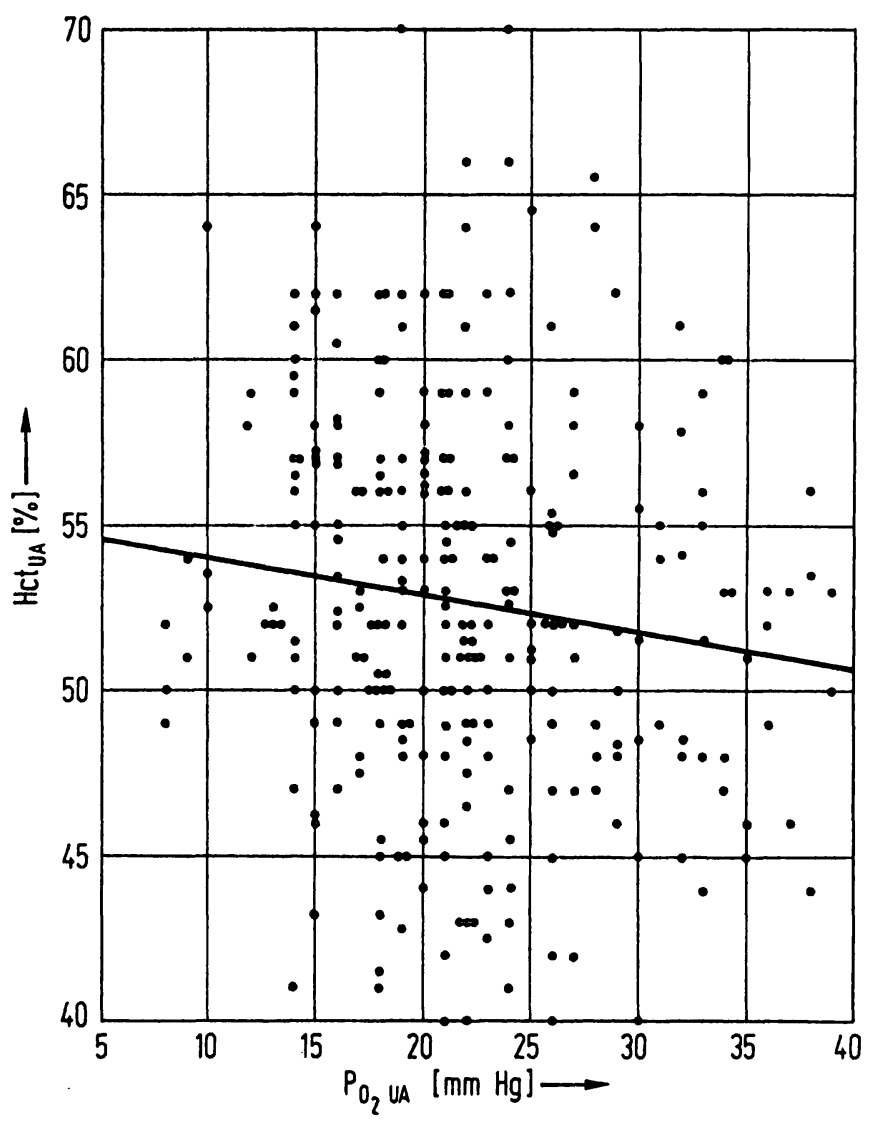

Fig. 5. Correlation between oxygen partial pressure $\left(\mathrm{PO}_{2} \mathrm{UA}_{\mathrm{A}}=\mathrm{x}\right)$ and hematocrit (HctuA $=\mathrm{y}$ ) in umbilical artery blood of 291 newborn infants immediatcly after delivery. Regression equation $\mathrm{y}=55.1-0.1 \mathrm{x} ; \mathrm{r}=0.12$, $\nu=289,2 x<0.1$. 


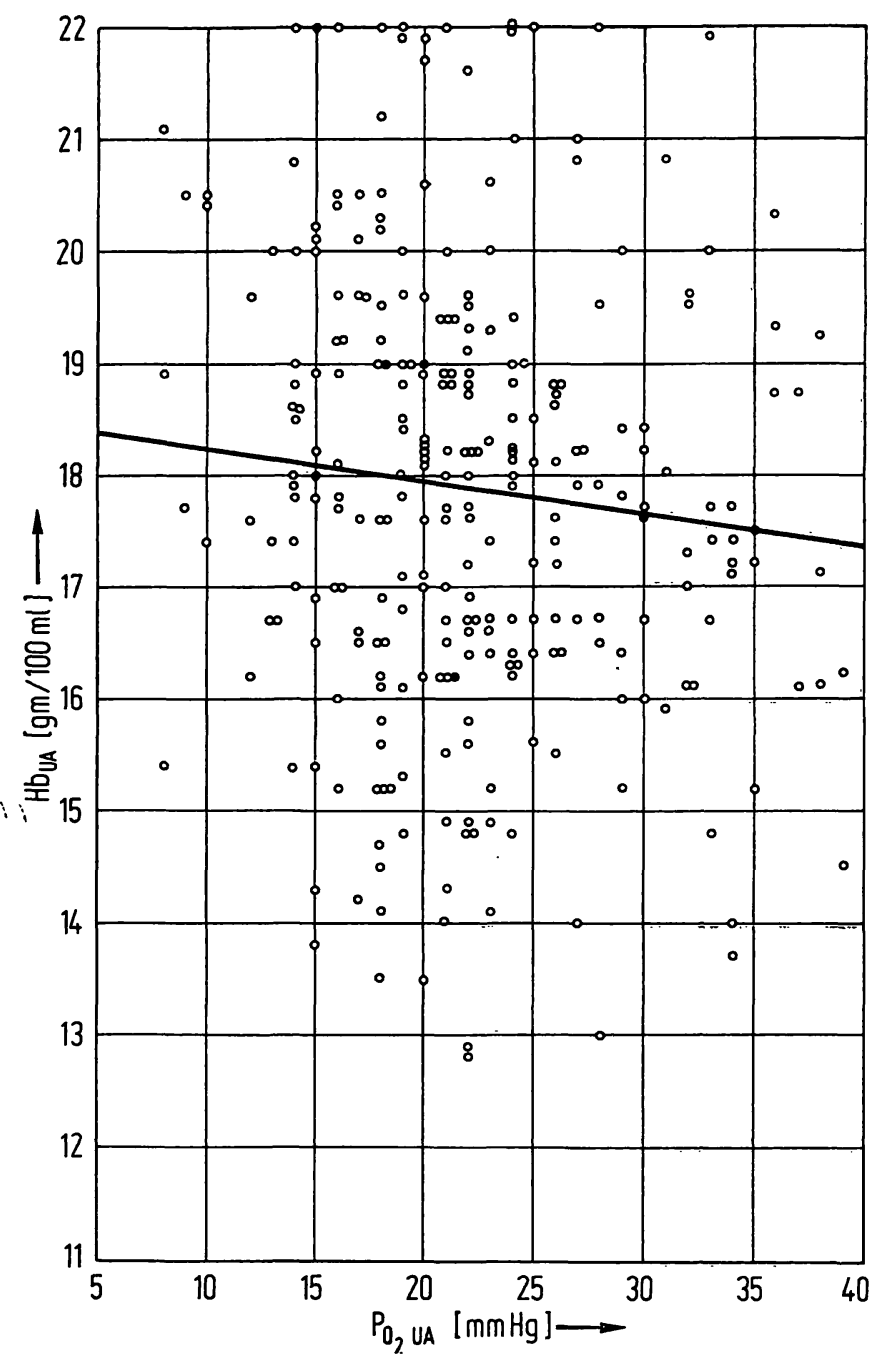

Fig. 6. Correlation between oxygen partial pressure $\left(\mathrm{PO}_{2} \mathrm{UA}_{\mathrm{A}}=\mathrm{x}\right)$ and hemoglobin concentration $\left(\mathrm{HbuA}_{\mathrm{A}}=\mathrm{y}\right)$ in umbilical artery blood of 291 newborn infants immediately after delivery. Regression equation $\mathrm{y}=18.5-0.03 \mathrm{x}$; $\mathbf{r}=0.10, v:=289,2 \alpha<0.1$.

genation during labor is temporarily and individually rather variable, as can be indirectly concluded from the large standard deviations in the mean $\mathrm{Po}_{2}$ values (Tabs. I and II). Naturally, under these conditions our single determinations of the momentary oxygen pressure in umbilical cord blood of the newborn immediately after delivery will give us only incomplete indications of the degree of fetal oxygenation during the preceding stage of labor, which profoundly influences the degree of acidity. It can also be assumed that oxygen deficiency does not bring about the increase in capillary permeability leading to hemoconcentration directly, but rather through the rise in acidity.

\section{Conclusions}

Our investigations demonstrate a definite dependence of the neonatal hemoconcentration on the concentration of hydrogen ions in the range from $\mathrm{pH} 7.00$ to 7.39 . In its strict meaning, this statement implies that data concerning the normal ranges of hematocrit and hemoglobin in neonatal blood immediately after delivery are fully valid only if the appropriate $\mathrm{pH}$-values are also cited. As a rule, acidotic neonates will show increased hematocrit and hemoglobin values in comparison to non-acidotic neonates.

In addition to these laboratory aspects, the acidity-induced hemoconcentration in the newborn infant may also be of clinical importance. Hemoconcentration, caused by enlarged capillary leakage and enhanced passage of blood fluid into the extravascular space, results in a diminution of the blood volume which in turn may negatively affect pressure and blood flow in the circulatory system. In addition, hemoconcentration is inevitably associated with an elevation of blood viscosity; an increase in hematocrit from 50 to 60 per cent, for instance, is equivalent to a rise in blood viscosity of approximately 1 centipoise [4]. Logically, both manifestations, namely reduction of the circulating blood volume and rise in blood viscosity, will certainly not improve the survival chances of an acidotic infant born in a depressed condition.

\section{Summary}

In the present study we investigated whether and to what extent the total acidity, the metabolic acidity and oxygen partial pressure influence the hematocrit and hemoglobin levels of newborn infants immediately after delivery.

314 term babies were examined immediately after delivery. In all subjects, determinations of hematocrit and hemo-

globin in umbilical artery blood were made, as well as assays of total acidity by potentiometric $\mathrm{pH}$ measurements. Furthermore, the metabolic acidity in umbilical artery blood was assayed in 277 of the newborn infants studied; the degree of metabolic acidity was estimated by $\mathrm{pH}$ measurements at a standard carbon dioxide pressure of $40 \mathrm{mmHg}$ (so-called pHqu40 values). In 281 subjects, 
measurements of the oxygen partial pressure in umbilical artery blood were made.

As can be shown (Figs. 1 and 2), there exist statistically significant correlations between blood total acidity on the one hand, and hematocrit and hemoglobin values on the other $(p<0.001$ and 0.01$)$. A definite decrease in blood $\mathrm{pH}$ leads to a definite rise in hematocrit and hemoglobin values. From the appropriate regression equations it can be calculated that, for instance, at a blood $\mathrm{pH}$ of 7.40 a hematocrit of 49.2 per cent and a hemoglobin value of 17.1 grams per $100 \mathrm{ml}$. of blood is to be expected. By contrast, at a blood $\mathrm{pH}$ of 7.00 the statistically most probable hematocrit and hemoglobin values will amount to 56.9 per cent and 19.1 grams per $100 \mathrm{ml}$. respectively.

The correlations between metabolic acidity and hematocrit or hemoglobin values (Figs. 2 and 4 ) are also statistically significant $(p<0.001)$. Between $\mathrm{pHqu} 407.40$ and 7.00 an increase in hematocrit from 48.9 to 59.5 per cent and in hemoglobin from 16.7 to 20.0 grams per $100 \mathrm{ml}$. of umbilical artery blood is to be expected. Notably, the correlations between metabolic acidity and hematocrit or hemoglobin values respectively are considerably closer than those between total acidity and hematocrit or hemoglobin values respectively.

In our random sample, no significant correlations between oxygen partial pressure, hematocrit and hemoglobin content in umbilical artery blood immediately after birth could be calculated (Figs. 5 and 6 ).

The almost parallel increase in hematocrit and hemoglobin values of the newborn infant during the rise of blood acidity can in all probability be explained by hemoconcentration due to increased capillary leakage and enhanced passage of blood fluid into the extravascular space. The diminution in blood volume related to descending blood $\mathrm{pH}$ values is inevitably associated with an increase in blood viscosity. In acidotic neonates born in poor condition, both manifestations may worsen the chances for survival.

Keywords: Newborn infant, umbilical cord blood, hematocrit, hemoglobin, acid-base equilibrium, oxygen deficiency, acidosis.

\section{Zusammenfassung}

Der Einfluß der Azidität auf die Hämatokrit- und Hämoglobinwerte bei Neugeborenen unmittelbar nach der Geburt

In der vorliegenden Arbeit wurde untersucht, ob und in welchem Ausmaß die Gesamtazidität, die metabolische Azidität und der Sauerstoff-Partialdruck die Hämatokrit- und Hämoglobinwerte von Neugeborenen ununmittelbar nach der Geburt beeinflußt.

314 ausgetragene Kinder wurden unmittelbar nach der Geburt untersucht. In allen Fällen wurden Hämatokritund Hämoglobinbestimmungen im Nabelarterienblut durchgeführt, sowie Bestimmungen der Gesamtazidität durch potentiometrische $\mathrm{pH}-$ Messung. Außerdem wurde bei 277 der untersuchten Neugeborenen die metabolische Azidität im Nabelarterienblut bestimmt; der Grad der metabolischen Azidität wurde mittels pH-Messungen bei einem Standard- $\mathrm{CO}_{2}$-Druck von $40 \mathrm{~mm} \mathrm{Hg}$ ermittelt (sogenannte pHqu40-Werte). In 281 Fällen wurden Messungen des Sauerstoffpartialdruckes im Nabelarterienblut vorgenommen.

Es konnte gezeigt werden (Abb. 1 und 3), daß zwischen der Blut-Gesamtazidität einerseits und den Hämatokritbzw. Hämoglobinwerten andererseits statistisch signifikante Korrelationen bestehen ( $p<0.001$ und 0.01). Abfall des Blut-pH um einen bestimmten Betrag führt zu einem definierten Anstieg der Hämatokrit- und Hämoglobinwerte. So kann zum Beispiel aus den zugehörigen Regressionsgleichungen berechnet werden, $\mathrm{da} \beta$ bei einem Blut-pH von 7.40 ein Hämatokrit von $49.2 \%$ und ein
Hämoglobinwert von $17.1 \mathrm{~g} / 100 \mathrm{ml}$ Blut zu erwarten ist. Bei einem Blut-pH von 7.00 würden die statistisch wahrscheinlichsten Hämatokrit- und Hämoglobinwerte dagegen $56.9 \%$ und $19.1 \mathrm{~g} / 100 \mathrm{ml}$ Blut betragen.

Die Korrelationen zwischen metabolischer Azdität und Hämatokrit- bzw. Hämoglobinwerten (Abb. 2 und 4) sind ebenfalls statistisch signifikant ( $p<0.001)$. Zwischen pHqu40 7.40 und 7.00 ist ein Anstieg des Hämatokrits von 48.9 auf $59.5 \%$ und des Hämoglobins von 16.7 auf $20.0 \mathrm{~g} / 100 \mathrm{ml}$ Nabelschnurblut $\mathrm{zu}$ erwarten. Bemerkenswerterweise sind die Korrelationen zwischen metabolischer Azidität und Hämatokrit- bzw. Hämoglobinwerten beträchtlich enger als jene zwischen Gesamtazidität und Hämatokrit- bzw. Hämoglobinwerten.

Bei unserem Stichprobenumfang konnten keine signifikanten Korrelationen zwischen Sauerstoff-Partialdruck, Hämatokrit und Hämoglobingehalt des Nabelarterienblutes unmittelbar nach der Geburt berechnet werden (Abb. 5 und 6).

Der nahezu parallele Ansticg der Hämatokrit- und Hämoglobinwerte beim Neugeborenen während des Anstieges der Blutazidität ist aller Wahrscheinlichkeit nach durch eine Hämokonzentration zu erklären, die durch erhöhte Kapillardurchlässigkeit und vermehrten Übertritt von Blutflüssigkeit in den extravaskulären Raum zustande kommen mag. Verminderung des Blutvolumens bei Abfall der Blut-pH-Werte führt unweigerlich $\mathrm{zu}$ einem Anstieg der Blutviskosität. Bei azidotischen Neugeborenen in: schlechtem Zustand können beide Erscheinungen die Überlebenschancen der Kinder verschlechtern.

Schlüsselwörter: Neugeborenes, Nabelschnurblut, Hämatokrit, Hämoglobin, Säure-Basen-Gleichgewicht, Sauerstoffmangel, Azidose. 


\section{Résumé}

Influence de l'acidité sur les valeurs d'hématocrite et d'hémoglobine chez les nouveaux-nés aussitôt après la naissance.

Le travail présent analyse l'influence de l'acidité totale, de l'acidité métabolique et de la pression partielle d'oxygène sur les valeurs d'hématocrite et d'hémoglobine chez les nouveaux-nés aussitôt après la naissance. 314 enfants venus à terme ont été examinés aussitôt après la naissance. Dans tous les cas, on a effectué des dosages d'hématocrite et d'hémoglobine dans le sang artériel ombilical et analysé l'acidité totale par le mesurage potentiométrique du pH. En outre, chez 277 de ces nouveaux-nés, on a mesuré l'acidité métabolique dans le sang artériel ombilical au moyen de mesurages du $\mathrm{pH}$ pour une pression standard de $\mathrm{CO}_{2}$ de $40 \mathrm{~mm} \mathrm{Hg}$ (valeurs dites pHqu40). Dans 281 cas, on a également procédé à des mesures de la pression partielle d'oxygène dans le sang artériel ombilical.

- Les résultats ont montré l'existence de corrélations statistiquement significatives $(p<0.001$ et 0.01$)$ entre l'acidité totale du sang d'une part et les valeurs respectives d'hématocrite et d'hémoglobine d'autre part. La baisse $\mathrm{du} \mathrm{pH}$ du sang provoque une hausse correspondante des valeurs d'hématocrite et d'hémoglobine. C'est ainsi, par exemple, que l'on peut calculer à partir des équations de régression corrélatives qu'à un $\mathrm{pH}$ du sang de 7.40 correspond en général un hématocrite de $\mathbf{4 9 . 2}$ pour cent et un taux d'hémoglobine de $17.1 \mathrm{~g} / 100 \mathrm{ml}$ de sàng. Par̀ contre, pour un $\mathrm{pH}$ du sang de 7.00 , les valeurs d'hématocrite et d'hémoglobine les plus probables selon les statisti- $\therefore$

ques monteraient à 56.9 pour cent à $19.1 \mathrm{~g} / 100 \mathrm{ml}$ de sang. Les corrélations entre l'acidité métabolique et les valeurs respectives d'hématocrite et d'hémoglobine sont, de même, statistiquement significatives $(p<0.001)$. Entre pH qu 407.40 et 7.00 , on a observé une hausse de l'hématocrite de 48.9 à 59.5 pur cent et de l'hémoglobine de 16.7 à $20.0 \mathrm{~g} / 100 \mathrm{ml}$ de sang du cordon ombilical. Il est intéressant de noter que les corrélations entre l'acidité métabolique et les valeurs d'hématocrite et d'hémoglobine sont beaucoup plus étroites qu'entre l'acidité totale et les valeurs d'hématocrite et d'hémoglobine.

Les analyses effectuées sur nos spécimens prélevés au hasard n'ont révélé aucune corrélation significative entre, d'une part, la pression partielle d'oxygène et, d'autre part, l'hématocrite et le taux d'hémoglobine du sang artériel ombilical aussitôt après la naissance.

Ia hausse quasiment parallèle chez le nouveau-né des valeurs d'hématocrite et d'hémoglobine d'une part et de l'acidité du sang d'autre part s'explique selon toute vraisemblance par une hémoconcentration résultant sans doute d'une perméabilité capillaire accrue et du passage renforcé de liquide sanguin dans le zone extravasculaire. Une diminution du volume sanguin consécutive à une baisse des valeurs $\mathrm{pH}$ du sang provoque inévitablement une augmêntation de la viscosité du sang. Chez les nouveaux-nés acidosiques en mauvais état, ces deux symptômes peuvent réduire les chances de survie des enfants.

Mots-clés: Nouveau-né, sang du cordon ombilical, hématocrite, hémoglobine, équilibre basacidique, hypoxygénie, acidose.

\section{Bibliography}

[1] Bacigalupo, G., E. SAling: Hämatokrit- und Hämoglobinwerte im Nabelschnurblut nicht-azidotischer und azidotischer Neugeborener. In: Dudenhausen, J. W., E. Saling: Perinatale Medizin Band IV. Thieme, Stuttgart 1973

[2] Bacigalupo, G., M. Mülinng, H. J. Henning, G. Kressin, K. WAGNER: Über einige Fragen des Adenylsäuresystems des Blutes bei kontrollierter Hypoxie (Modellversuche am Schwein). In: SAling, E., J. W. Dudenhausen: Perinatale Medizin Band III. Thieme, Stuttgart 1972

[3] van Kampen, E. J., W. G. Zijlstra: Standardization of hemiglobinometry: II. The hemiglobincyanide method. Clin. Chim. Acta 6 (1961) 538
[4] Pirofsky, B.: The determination of blood viscosity in man by a method based on Poiseuille's law. J. Clin. Invest. 32 (1953) 292

[5] SAling, E.: Zustandsdiagnose beim Neugeborenen unmittelbar nach der Geburt. Gynaecologia 160 (1965) 133

[6] Saling, E.: Fetal and neonatal hypoxia in relation to clinical obstetric practice. Edward Arnold (Publishers) Ltd., London 1968

[7] Strumia, M. M., A. B. SAmple, E. D. Hart: Improved microhematocrit method. Amer. J, Clin. Pathol. 24 (1954) 1016; Correction: Amer. J. Clin. Pathol. 25 (1955) 298
Priv.-Doz. Dr. med. habil. G. Bacigalupo

Arbeitsgruppe für perinatale Medizin

der Freien Universität Berlin

D-1000 Berlin 44

Mariendorfer Weg 28-38

Germany 